\title{
Hatay İlinin Portakal Üretimi ve Dış Ticarette İşletmelerin Pazarlama Stratejileri
}

\author{
Tuğçe KIZILTUĞ ${ }^{1} \mathscr{P}$, Halil FİDAN ${ }^{2}$ (D) \\ ${ }^{1}$ Hatay Mustafa Kemal Üniversitesi Ziraat Fakültesi Tarım Ekonomisi Bölümü Hatay, ${ }^{2}$ Ankara Üniversitesi Ziraat Fakültesi Tarım Ekonomisi \\ Bölümü, Ankara \\ ${ }^{1}$ https://orcid.org/0000-0002-5119-8788, ${ }^{2}$ https://orcid.org/0000-0002-9934-8167 \\ $\varpi$ : tkiziltug@mku.edu.tr
}

\section{ÖZET}

$\mathrm{Bu}$ araştırmanın amacı, Hatay ilinde portakal ihracatı yapan işletmelerin uluslararası pazarlarda uyguladıkları stratejilerin belirlenmesi ve ihracatta yaşanılan sorunların değerlendirilmesine yöneliktir. Çalışmada, kullanılan anketler yüz yüze görüşme yoluyla işletmelere uygulanmış olup, 41 işletme yetkilileri ile görüşülmüş ve elde edilen veriler, 2014-2015 dönemini kapsamaktadır. Anket sonuçlarına göre; işletmeler farklılaştırılmış pazarlama stratejisini benimsemiş oldukları, dış pazarlardaki fiyatlandırmanın piyasa fiyatlarına göre yapıldığı, dış pazarlarda ürün kalitesi rekabet edilebilirliği artırdığı belirlenmiştir. Portakal ihraç eden işletmelerin yöneldiği en önemli pazarlar Rusya ve Ortadoğu ülkeleridir. Ayrıca bu işletmeler yeni pazarlara yönelmek yerine mevcut pazarlarını korumak istemektedirler. Fakat mevcut pazarlarını korumak adına tutundurma faaliyetlerine ve Ar-Ge çalışmalarına da yeterince önem vermemektedirler. Ayrıca işletmelerin, taşıma, ambalajlama, depolama gibi problemlerden dolayı \%10-15 oranında ürün kaybı yaşadıkları anlaşılmaktadır. Bu nedenle, bu ürünleri imha etmekte ya da daha az seçici ülkelere göndermeyi tercih etmektedirler. İşletmelerin denizyolu taşımacılığında ciddi sıkıntılar yaşadıkları ve devlet kuruluşlarınca ihracatın desteklenmesi konusunda bir beklenti içinde oldukları saptanmıştır.
Araştırma Makalesi

$\begin{array}{ll}\text { Makale Tarihçesi } \\ \text { Geliş Tarihi } & : 26.10 .2018 \\ \text { Kabul Tarihi } & : 03.12 .2018\end{array}$

Anahtar Kelimeler

Diş ticaret

Pazarlama stratejisi

Portakal dış piyasası

Uluslararası pazarlama

\section{Orange Production and Foreign Trade Business Marketing Strategies in Hatay Province}

\section{ABSTRACT}

The aims of this study were to determine marketing strategies of orange exporters in Hatay city, and evaluating the problems about orange exportation. The primary data of the study were collected by face to face interview method from 41 orange exporters during $2014-$ 2015. The research results indicated that companies were mostly adopted to differentiated marketing strategies, they were determining their product prices according to the market prices, and product quality increases the competitiveness. It was also found out that, main markets of the companies were commonly Russia and Middle East countries, and they were intended to protect their existing markets instead of finding new markets. However, it was also found that promotional and R\&D activities were insufficient in order to protect their existing markets. Additionally, there was yield lost around 10$15 \%$ due to the problems derive from transportation, packaging and storing and etc. In that case, either they were disposing their products or selling to the countries which were not selective. Lastly, it was determined that companies were facing to difficulties in shipment by seaway, and they had an expectation about better subsidies for exportation by government organizations.

\section{Research Article}

$\begin{array}{ll}\text { Article History } & \\ \text { Received } & : 26.10 .2018 \\ \text { Accepted } & : 03.12 .2018\end{array}$

Keywords

Foreign trade

Marketing strategy

Orange foreign marketing

International marketing

To Cite : Kızıltuğ T, Fidan H 2019. Hatay İlinin Portakal Üretimi ve Dış Ticarette İşletmelerin Pazarlama Stratejileri. KSÜ Tarım ve Doğa Derg 22(2): 281-293. DOI: 10.18016/ksutarimdoga.vi.464168 


\section{GİRIŞ}

Turunçgil sadece tropik ve subtropik bölgelerde yetişmesi üretim ve dış ticaretindeki doğal monopol önemini vurgulanmaktadır. Dünyada 9.6 milyon hektar turunçgil üretim alanından 135 milyon ton ürün elde edilmektedir. Dünyadaki bu üretimin \%42.3'ü portakal üretimine aittir. Portakal, turunçgiller içinde en yüksek üretim miktarı ve oranına orana sahiptir. Dünyada üretim alanı 4.06 milyon ha, üretim miktarı ise 71 milyon tondur. Turunçgil üretiminin dış ticarete konu edilen kısmının \%52'si ihracatta, \%48'i ise ithalatta kullanılmaktadır. Dünyada en fazla turunçgil ihracatı yapan ülkeler İspanya ve ABD; en fazla ithalat yapan ülkeler ise Rusya ve Almanya'dır. Turunçgil ihracatının \%59'unu portakal oluşturmaktadır. Portakal ihracatında söz sahibi olan ülkeler İspanya ve Güney Afrika; ithalatında ise Rusya ve Irak'tır (Anonymus, 2013). Dünyadaki turunçgil piyasasının gelişmiş olması ülkeler arasında yoğun bir rekabet ortamı yaratmaktadır. Özellikle yetiştirme alanının uygunluğu açısından üretimin belirli ülkelerle sınırlı olması ve tüketimin ise ülkeler arasında yaygınlaşması rekabette bazen bozulmalar meydana getirse de piyasa ekonomisi içinde rekabet hala yerini korumaktadır. Bu rekabet ortamında pazardan pay almak, pazar payını artırarak ihracat gelirini yükseltmek açısından uygun pazarlama stratejilerini geliştirmek ve uygulamak önemlidir. $\mathrm{Bu}$ açıdan rekabette ve strateji belirlemede ülkenin pazara giriş şekli, rakiplerin özellikleri, ithalatçı ülkelerin uyguladığı gümrük tarifeleri, ihracata verdiği teşvikler ve dağıtım kanalları gibi dış çevre faktörleri büyük önem taşımaktadır.

Türkiye'de 3 milyon ton turunçgil üretiminin yaklaşık 1.7 milyon tonunu portakal, 942 bin tonunu mandalina, 726 bin tonunu limon, 228 bin tonunu greyfurt ve 2 bin tonunu da turunç oluşturmaktadır. Dünya'da olduğu gibi Türkiye'de de en fazla portakal üretimi yapılmaktadır (Anonim, 2013). 2014 yılı itibariyle portakal üretiminin \%25'i Adana, \%23’ü Mersin, \%17'si Hatay ve \%16'sı Antalya tarafindan karşılanmaktadır. Bölge toplam üretimin yaklaşık \%83'ünü gerçekleştirmektedir. Dünya portakal üretiminin \%2.5’i gibi çok az bir kısmını karşılayan Türkiye, ürettiği portakalın \%19'unu ihraç etmektedir. Türkiye'nin bu alanda, dış pazarlara yeterince yönelmediği görülmektedir. Bunun başlıca sebepleri arasında işletmelerin pazar araştırmasına gereken önemi vermemesi ve yeni pazarlara girmede çekincelerinin olması gösterilebilir. Türkiye'nin iklim koşulları ve konumu nedeniyle dünya piyasasında yerini almasının yanında erkenci çeşitlerin yetiştirilmesi, dünya piyasasındaki yoğun rekabette avantaj sağlamaktadır. Türkiye'de turunçgil yetiştiriciliği Ege ve Akdeniz kıyılarında, kısmen de Doğu Karadeniz Bölgesi'nde yapılmaktadır (Anonim
2010). Turunçgil üretiminin \% 95’i Ege ve Akdeniz bölgesinde gerçekleştirilmektedir. Bu nedenle ihracat firmaları özellikle Akdeniz Bölgesi'ni tercih etmektedirler. Türkiye genelinde bulunan yaklaşık 567 turunçgil ihracatı yapan firma bulunmakta ve bu firmaların 425 tanesi (\%75) Akdeniz Bölgesi'nde bulunmaktadır. En çok işletmenin bulunduğu iller Mersin, Hatay, Antalya ve Adana'dır (Anonim 2016). İşletmelerin çok olması aynı zamanda rekabeti de beraberinde getirmektedir. Dış ticarette uygulanan doğru stratejiler, beraberinde işletmenin satış grafiğindeki artışı ve işletme karını olumlu yönde destekleyebilir. $\mathrm{Bu}$ nedenle bu bölgedeki turunçgil ihracatı yapan işletmelerin yoğunluğu Türkiye'nin genel durumunu yansitabilir. Akdeniz Bölgesi'nde en fazla işletmeye sahip olan iller arasında Hatay'ın olması, ihracatın gelişmiş olması ve sınır bölgesine yakınlığı araştırma alanının seçiminde rol oynamıştır. Hatay ilinin Türkiye'nin portakal ihtiyacının \%17'sini karşıladığı düşünülürse, Ortadoğu sınırına yakınlığı ve deniz taşımacılığına uygunluğu taşıma maliyetleri açısından sağlayacağı avantaj, dış pazarlar açısından oldukça önemli sayılabilir. Hatay ilinde Erzin ve Dörtyol portakal bahçelerinin yoğunlukta bulunduğu ilçelerdir ve bu yüzden portakal üretiminin merkezi olarak söylenebilir. İlde portakal üretiminin \%85’i bu iki ilçe tarafından karşılanmaktadır. Üretimin geriye kalan kısmını İskenderun, Samandağ ve Merkez ilçeleri gerçekleştirmektedir.

Bu çalışmada, portakal ihracatı yapan işletmelerin dış pazar stratejileri incelenmiştir. İncelemenin yapıldığ Hatay ilinde işletmelerin portakal dış pazarında izledikleri pazarlama stratejileri, dağıtım kanalları, ürün gelişimi, fiyat belirleme, promosyon faaliyetleri, pazar bölümleme, konumlama, yasal mevzuatlar, marka, etiketleme vb. gibi konular ve bu konularda yaşanan sorunlar ele alınarak çözüm önerileri ortaya konulmaya çalışılmıştır. Ayrıca, Hatay ilinde ihracatı etkileyen faktörlerin saptanması, firmaların yurt dışı pazarlarına giriş şekilleri, hala uygulamakta oldukları stratejiler ve ülke politikalarının ihracata etkileri de ele alınmıştır.

Çalışmanın konusuna yakın olarak yapılan başlıca araştırmalar; Sarı (2007) tarafından yapılan çalışmada, firmaların dış pazarlarda ürün kalitesi ve fiyat kadar hizmet kalitesinin de önemli bir ölçüt olduğunu belirtmiştir. Uluslararası pazarlarda işletmeler müşteri memnuniyeti için, ürün kalitesi ve fiyat faktörleriyle birlikte stratejilerini belirlemeye başladıklarını belirtmişlerdir. Zenginoğlu (2007) yılında $\mathrm{AB}$ sürecinde turunçgil ihracatının yapısı ve ortaya çıkan sorunlar üzerine bir çalışma yapmıştır. Bu çalışmada AB üyeliği için gerekli olan Ortak Tarım Politikaları ve Meyve Sebze Ortak Pazar Piyasa Düzenine uyumunu ve ortaya çıkabilecek sorunları incelenmiştir. Alipour vd. (2013) Mazandaran ilinde 
turunçgil üretimi ve ihracat pazarlama stratejileri üzerine yaptığı çalışmasında, turunçgil üretimin ilde azalma sebeplerini incelemiştir. Çalışmaya göre, turunçgilin ekonomik değerinin petrole kıyasla daha az olması sebebiyle petrol üzerine odaklanılmış olması, üretimin geniş bir alanda yapılmaması ve üretim maliyetlerinin yüksek olmasından kaynaklandığını belirtmişlerdir. Ayrıca turunçgil ürünlerinin ithalatçı ülkelerin istedikleri kalitede olmaması, hasat, taşıma ve depolama sırasında ürün kayıplarının olmasının da ihracatı etkilediğini ifade etmişlerdir. Bununla birlikte paketleme, sinırlandirma ve dereceleme teknolojilerinin geliştirilmesi gerektiği sonucunu ortaya koymuşlardır. Güven (2010) 'Adana ilinde turunçgillerin pazarlama yapısı ve sorunları' konulu çalışmasında, ürünlerin kilo ve götürü usulü olmak üzere iki şekilde pazarlandığını belirtmiştir. Paketleme evi ve soğuk oda depolarının yeterince olmaması üreticilerin alıcılar karşında fiyat belirlemede zayıf olduğunu belirtmiştir. Ayrıca ihracatta karayolu ve denizyolu taşımacılığına önem verilmesi ve gemi taşımacılığında soğutuculu gemi sayısının artırılması gerektiğini ortaya koymuştur.

\section{MATERYAL ve METOT}

Araştırmanın ana materyalini oluşturan birincil veriler Hatay ilinden portakal ihracatı ve dış pazarlaması yapan firmalarla yüz-yüze görüşme yöntemiyle yapılan anket çalışmalarından elde edilmiştir. Örnekleme aşamasında tam sayım yöntemine göre portakal ihracatı yapan işletmelerin tamamı ile anket yapılmıştır. AKİB (Akdeniz İhracatçılar Birliği)'den alınan bilgiler dahilinde 103 işletme olması, zaman ve maddi kısıt olmaması nedeniyle örnekleme yapmak yerine tam sayım yöntemi seçilmiştir. Anket çalışmasının yapıldığı dönemde faaliyette olan işletme sayısının 45 adet olduğu tespit edilmiştir. $\mathrm{Bu}$ işletmelerden 41 tanesinden elde edilen bilgiler ana kitleyi temsil etmektedir. Bu işletmelere yapılan anketlerin ilçelere dağılımı Antakya 26 adet, Samandağ 4 adet, Dörtyol 6 adet, Erzin 3 adet ve Reyhanlı ve İskenderun 1 adet şeklindedir. Anket uygulaması 25 Mayıs-3 Temmuz 2015 tarihleri arasında gerçekleştirilmiştir. Anketteki bilgiler işletmelerin bir önceki yıla ait verilerine dayanmaktadır. İ̧̧letmelerin ihraç ettikleri portakal miktarları ele alınarak miktar kriterine göre sıraya dizilmiş, dağılımda homojenlik sağlanmış ve tek tabakada normal dağılım gösterdiği için tek grup halinde ele alınmıştır. Anketlerden elde edilen veriler, SPSS istatistik programinda analiz edilmiştir. Araştırma temel istatistik yöntemleri (çizelge analizi, frekans dağılımı, aritmetik ortalama ve oransal hesaplamalar) ve Likert Ölçeği kullanılarak (ortalama ve standart sapma) analiz edilmiştir. Ayrıca verilerin analizinde soruların birbiriyle ilişkilerini incelemek üzere hipotezler kurularak Ki-Kare bağımsızlık testi kullanılmıştır. Ki-Kare bağımsızlık testinin gösterimi aşağıdaki denklemde gösterildiği gibidir.

$$
\begin{aligned}
\text { Esitlik 1: } & \begin{aligned}
B_{11}=\frac{R_{1} x C_{1}}{N}, B_{12} & =\frac{R_{1} x C_{2}}{N}, \ldots \ldots, B_{r c} \\
& =\frac{R_{r} x C_{c}}{N} \quad\left(\sum G_{i j}=\sum B_{i j}\right)
\end{aligned}
\end{aligned}
$$

İlk olarak $\mathrm{N}$ birimlik örneklem sayı belirlenerek iki değişkene ayrılarak sınıflandırılır. Birinci değişken olarak R satırından bir gözlem değeri ile ikinci değişken olarak kullanılan $\mathrm{C}$ sütundan biriyle birleştirilerek $\mathrm{R} \times \mathrm{C}$ çapraz tablolar oluşturulur. İ. satır ve $\mathrm{j}$. sütunla birleşen gözlemlerin sayısı gözlemlenen frekans şeklinde $\mathrm{G}_{\mathrm{ij}}$ ile gösterilmektedir (Uzgören 2012).

\section{BULGULAR ve TARTIŞMA}

\section{Portakal Ihracatı Yapan Işletmelerin Yapısı}

Firmalar, Hatay'ın 15 ilçesi içerisinde daha çok 6 ilçede bulunmakta ve özelliklede Antakya ilçesinde yoğunluk göstermektedir. Portakal ihracatı yapan işletmelerin \%63'ü Antakya'da, \%14'ü Dörtyol ve \%9.8'i Samandağ ilçelerinde bulunmaktadır. Portakal üretiminin yoğun olduğu Dörtyol, Erzin ve Samandağ ilçelerinde daha çok üretim yapılan bahçeler bulunmaktadır. İşletmelerdeki daimi çalışanların yoğunluğu incelendiğinde; işletmelerin yoğun olarak $1-10$ arası (\%39) ve $11-20$ arası $(\% 31,7)$ işçi çalıştırmada yoğunlaştığı görülmektedir. Ayrıca görüşülen işletmeler yaklaşık 900 kişi daimi işçi olarak çalışırken, işletmelerin 33 tanesi de yaklaşık 3500 geçici iş̧̧i çalıştırmaktadır.

Yüksek eğitim seviyesine sahip bireylerin daha fazla maddi kazanç elde ettikleri, daha az işsizlik riski ile karşılaştıkları ve daha iyi kariyerlere sahip oldukları Psacharopoulos ve Patrions (2002) tarafindan yapilan çalışmada belirlenmiştir. Eğitim düzeyi ve kazanç arasında pozitif bir etki olduğu düşünülmesine rağmen dış etkenler ülkenin ekonomik durumu ve kişinin bireysel yetenek ve uygun iş seçimindeki hatalar bu etkiyi ters yönde etkileyebilmektedir (Çalışkan 2007).

Çizelge 1'e göre firma sahiplerinin eğitim düzeyi ve kazançları hakkında gözlenen ve beklenen değerler gösterilmektedir. Bu tabloda ki-kare testi uygulanmış ve $\mathrm{X}^{2}=4.511$ ve $\mathrm{p}>0.05$ olduğundan $\mathrm{H}_{0}$ hipotezi reddedilir ve eğitim ve gelir seviyesi arasında $\% 5$ anlamlılık düzeyine göre ilişki olmadiğına karar verilmiştir. Buna göre firma sahiplerinin eğitim düzeyi arttıkça kazançlarının da arttığı konusunda istatistiki açıdan anlamlı bir sonuç bulunamamıştır. Elde edilen bu bulgular, Çalışkan'ın (2007) ve Sarı'nın (2002) yaptığı çalışmalarda eğitim seviyesi yükseldikçe gelirin arttığı ve en yüksek gelirin lisans düzeyinde 
olduğu sonucu ile farklılık göstermektedir. Tarım sektöründe, eğitim seviyesinin yüksek kişilerin geliri ile ilişki olmamasının sebepleri, eğitim seviyesi yükseldikçe tarımdan uzaklaşması, geleneksel yöntemlere bağlllık ve teknolojinin tarım sektörüne geç girmesi şeklinde sıralanabilir.
Çalışma süreci boyunca edinilen deneyim yıllar itibariyle kazançta artışa neden olmaktadır. Günümüzde de firmalarda çalışan, işine yıllarını veren personel ile yeni çalışmaya başlayan personelin aynı maaşı almadığı, deneyime göre bir gelir artışı olduğu aşikârdır. Tecrübe ve eğitim düzeyindeki paralel artış kazancı olumlu etkilemektedir.

Çizelge 1. Eğitim-Gelir ilişkisi

\begin{tabular}{|c|c|c|c|c|c|c|c|c|c|c|c|}
\hline \multirow{2}{*}{ Eğitim Seviyesi } & \multicolumn{2}{|c|}{1 milyon $\$$ az } & \multicolumn{2}{|c|}{$\begin{array}{l}1-4.99 \\
\text { milyon } \$\end{array}$} & \multicolumn{2}{|c|}{ 5- 9.99 milyon $\$$} & \multicolumn{2}{|c|}{ 10- 14.99 milyon $\$$} & \multicolumn{2}{|c|}{15 milyon $\$$ üzeri } & \multirow[t]{2}{*}{ Toplam } \\
\hline & $\mathrm{G}$ & $\mathrm{B}$ & $\mathrm{G}$ & $\mathrm{B}$ & $G$ & $\mathrm{~B}$ & $\mathrm{G}$ & $\mathrm{B}$ & G & $\mathrm{B}$ & \\
\hline Lisans Öncesi & 4 & 3.6 & 7 & 5.1 & 4 & 3.1 & 2 & 2.6 & 4 & 6.7 & 21 \\
\hline Lisans Sonrası & 3 & 3.4 & 3 & 4.9 & 2 & 2.9 & 3 & 2.4 & 9 & 6.3 & 20 \\
\hline Toplam & 7 & 7.0 & 10 & 10 & 6 & 6.0 & 5 & 5.0 & 13 & 13.0 & 41 \\
\hline
\end{tabular}

Anlamlılık Değeri (Sig): 0.341; X²=4.511; df=4; G: Gözlenen; B: Beklenen

$\mathrm{H}_{0}$ : Firma sahiplerinin eğitim düzeyi ile firmanın yıllık geliri arasında ilişki vardır.

$\mathrm{H}_{1}$ : Firma sahiplerinin eğitim düzeyi ile firmanın yıllık geliri arasında ilişki yoktur.

Çizelge 2'ye göre firma sahiplerinin deneyim düzeyi arttıkça kazançlarının da arttığına dair sonuçlar istatistiki açıdan anlamlı bulunmamıştır. Bu tabloda ki-kare testi uygulanmış ve $\mathrm{X}^{2}=15.760$ ve $\mathrm{p}>0.05$ olduğundan $\mathrm{H}_{0}$ hipotezi reddedilir. $\mathrm{Bu}$ duruma göre gelir ile deneyim arasında $\% 5$ anlamlılık düzeyine göre bir ilişki olmadığına karar verilmiştir. Çalışkan'ın (2007) yaptığı çalışmada kazancın iş tecrübesi üzerine etkisinin olumlu olduğunu ve 1 ylllık iş tecrübesinin yıllık kazanca \%1.6 oranında artış sağladığını ortaya çıkarmıştır. Sonuçlardan elde edilen bulgulara göre, Çalışkan'ın çalışması ile paralellik göstermediği sonucuna varılmıştır. Çünkü tarım sektörünün iklim şartlarına olan bağlılığı, aile ihtiyacını karşılamaya yönelik üretimlerin yapılması ve aile işgücünün ön planda olması geliri etkilemekte fakat deneyimle ilişkili değildir. Tarım sektöründe deneyim yapılacak yanlışları önleyebilir ama geliri artırmadaki etkisi daha azdır.

Ayrıca elde edilen bulgular ışı̆̆ında anket yapılan firma sahiplerinin ortalama yaşı 41 olup, bu alandaki tecrübeleri ortalama 15 yıldır. Çalışmada işletme sahiplerinin \%70'nin sektördeki çalışma süreleri on yıldan fazladır. Zenginoğlu 2007 yılında yaptığ çalışmada Türkiye'deki turunçgil firmalarına yaptığı ankette ortalama yaşı 39.35 , alandaki deneyim sürelerini ise 9.41 yll olarak bulmuştur.

Çizelge 2. Deneyim- Gelir ilişkisi

\begin{tabular}{|c|c|c|c|c|c|c|c|c|c|c|c|}
\hline \multirow{2}{*}{$\begin{array}{l}\text { Çalışma } \\
\text { Süresi }\end{array}$} & \multicolumn{2}{|c|}{1 milyon $\$$ az } & \multicolumn{2}{|c|}{$1-4.99$ milyon $\$$} & \multicolumn{2}{|c|}{$5-9.99$ milyon $\$$} & \multicolumn{2}{|c|}{$10-14.99$ milyon $\$$} & \multicolumn{2}{|c|}{15 milyon $\$$ üzeri } & \multirow{2}{*}{ Toplam } \\
\hline & $\mathrm{G}$ & $\mathrm{B}$ & $\mathrm{G}$ & $\mathrm{B}$ & $\mathrm{G}$ & $\mathrm{B}$ & $\mathrm{G}$ & $\mathrm{B}$ & $\mathrm{G}$ & $\mathrm{B}$ & \\
\hline $1-10$ & 5 & 2.6 & 2 & 3.7 & 3 & 2.2 & 1 & 1.8 & 4 & 4.8 & 15 \\
\hline $11-20$ & 2 & 3.1 & 6 & 4.4 & 1 & 2.6 & 3 & 2.2 & 6 & 5.7 & 18 \\
\hline $21-30$ & 0 & 0.9 & 2 & 1.2 & 0 & 0.7 & 1 & 0.6 & 2 & 1.6 & 5 \\
\hline 30 ve üzeri & 0 & 0.5 & 0 & 0.7 & 2 & 0.4 & 0 & 0.4 & 1 & 1.0 & 3 \\
\hline Toplam & 7 & 7.0 & 10 & 10 & 6 & 6.0 & 5 & 5.0 & 13 & 13.0 & 41 \\
\hline
\end{tabular}

Anlamlılık Değeri (Sig.): 0.202; X²=15.760; df=12; G: Gözlenen; B: Beklenen

$\mathrm{H}_{0}$ : Firma sahiplerinin deneyimi ile firmanın yıllık gelir arasında ilişki vardır.

$\mathrm{H}_{1}$ : Firma sahiplerinin deneyimi ile firmanın yıllık gelir arasında ilişki yoktur.

Anket yapılan firmalara ana faaliyet alanları sorulduğunda \%80'i sadece tarımsal faaliyette bulunurken, \%20'si (8 adet) hem tarımsal hem de tarım dışı faaliyet yapmaktadır. İşletmelerin faaliyet yapısına bakıldığında çoğunlukla (\%68.29) sadece ihracat yapan firmalardan oluşmaktadır. Bu firmalar üretim yapmamakta ve ürünlerini Hatay'daki üreticilerin bahçesinden ya da tüccarlardan temin etmektedirler. Faaliyet yapısı Üretici-İhracatçı olan işletmeler ise \%26.83'ünü oluşturmaktadırlar. $\mathrm{Bu}$ gruptaki firmalar değişen oranlarda hem üretici hem de ihracatçıdır.

Portakalın az bir miktarını kendi bahçelerinde yetiştirmekte, kalan kısmını üretici bahçelerinden veya hallerden temin etmektedirler. Geriye kalan kısmın faaliyet yapısı da ihracatçı-ithalatçı ve üreticiihracatçı-ithalatçı şeklindedir. Hatay'daki portakal ihracatı yapan firmaların büyük bir çoğunluğu sadece ihracata yönelerek, işletme içi bölünmeleri minimum düzeyde tutulması bir anlamda uzmanlaşmayı ifade etmektedir. 


\section{Portakal İhracatı Yapan İşletmelerin Pazarlama} Stratejileri

\section{Pazara Giriş Stratejileri}

Uluslararası pazarlara girmenin en kolay yolu tesadüfi yapılan ihracattır. Firmalar içinde ülke ekonomisi için de büyümeyi sağlayan bir faktördür. İhracata başlamanın temel sebebi olarak yerel pazarların doygun hale gelmesi ve satışlarını zamanla artırma isteğidir (Ahmed ve ark. 2006). Bu nedenle işletmelerin uluslararası pazarlara giriş stratejileri dolaylı ihracat, doğrudan ihracat, lisans anlaşmaları, Franchising, sözleşmeli üretim, ortak girişim ve yabancı direkt yatırımlar şeklinde sıralanabilir. Tarımsal ürünlerin pazarlanmasında en fazla kullanılan stratejiler dolaylı ihracat, doğrudan ihracat, sözleşmeli üretim ve ortak girişim şeklinde söylenebilir. Hatay'da portakal ihracatı yapan işletmeler uluslararası pazarlara ilk girişlerinde firmaların yaklaşı \%50'si genellikle diğer başlı̆̆ altındaki kendi çabaları ile başladıklarını belirtmişlerdir. Kalan \%31.7’lik kısımda ortak girişim ile başlamayı tercih etmiştir. Ortak girişimi tercih eden firmalar genellikle büyük firmaların taşıma kısminda yer alarak veya firma bünyesinde çalışanların ayrılıp kendi firmasını kurması ile oluşan bir ortaklık şeklinde gelişmiştir (yurt içi ortaklık hareketi).

Portakal ihracatı yapan firmaların büyük çoğunluğu Irak, Rusya ve Ukrayna ülkelerine yönelmişlerdir. Portakal ihracatı yapan işletmelerin \%75.6'sı Irak'a, \%68.3'ü Rusya'ya ve \%56.1'i ise Ukrayna'ya ürün göndermektedir. Burada pazara ilk girişte tesadüfi ihracat şeklinde bir satışın yapılmış olduğu söylenebilir. Zenginoğlu'nun yaptığı çalışmada, en çok turunçgil ihracatı yapılan ülkeler AB, Balkan Ülkeleri ve Rusya olduğu; Karadeniz'in (2004) Antalya'da turunçgil ihracatı üzerine yaptığı çalışmada en fazla ihracat yapılan ülkeler olarak Almanya, Hollanda, Yunanistan, Rusya ve Çek Cumhuriyeti olarak ifade edilmiştir. Anket sonucunda elde edilen bilgiler, bu iki çalışma ile karşılaştırıldığında; Hatay ilindeki işletmelerin ihracat potansiyelini farklı ülkelere yöneltmiş ve bu potansiyelini Rusya, Ukrayna ve Ortadoğu ülkelerinde kullanmaktadır. Bu durum ülkenin yurtdışı piyasalarında pazar payını artırmasını sağlarken; ülkenin tanınırlığını artırmaktadır. Ayrıca işletmeler her ülke için farklı pazarlama strateji uygulamakta oldukları için farklılaştırılmış Pazar stratejisini benimsendiğini sonucuna varılabilir.

İhracat yapan işletmelerin dış pazarlarda rekabet durumları incelendiğinde, \%46.3' sadece Türk ihracatçlar ile rekabet ederken, \%39.0 'u hem Türk ihracatçılar ile hem de diğer ülke ihracatçıları ile rekabet etmektedir. Dış pazarlarda bile rekabet Türk ihracatçılarla yapılmaktadır. İşletmelerin rakip oldukları noktaların başında ise fiyat ve kalite gelmektedir. Kaliteli ürünü düşük fiyatlara alma algısı her ne kadar yaygın olsa da kaliteli ürün pahalıdir.

İşletmelerin hedef pazar seçimlerine göre \%68.3 oranında sadece yurtdışı iken \%31,7'si de hem yurtdışı hem de yurtiçi pazarı ile ilgilenmektedir. Yurtiçi satışlar büyük ölçüde zorunluluk halinde gerçekleşmekte olduğunu belirtmişlerdir. Çünkü işletmeler ihracattan kazanacakları dövizden zorunluluk olmadığı sürece vazgeçmeyecektir. Zorunlulukla ifade edilen durumlar dereceleme ve standizasyonu uygun olmayan ürünler, gümrüklerden geri dönen ürünler vb. şekilde sıralanabilir. Firmanın hedef pazar seçimindeki kararın gelir seviyesinde bir artış yarattığına dair sonuçlar istatistiki açıdan anlamlı bulunmamıştır. Bu tabloda ki-kare testi uygulanmış ve $\mathrm{X}^{2}=7.143$ ve $\mathrm{p}>0.05$ olduğundan $\mathrm{H} 0$ hipotezi reddedilir. Bu duruma göre gelir ve hedef pazar seçimi arasında \%5 anlamlılık düzeyine göre aralarında bir ilişki bulunmadığ (Çizelge 3). Uygulanan anketler sonucunda firmalar hedef pazarı seçerken 41 firma içerisinde 32 işletme (\%78) ki bu neredeyse tamamına yakınını kapsamakta, pazar yapısı durumuna göre değerlendirdiğini belirtmiştir.

Pazar yapısından sonra gelen en önemli ölçüt ise ürünün özelliği olmuştur ve bu ölçütü 14 işletme (\%34.1) oluşturmaktadır. Ürün özelliğini seçen firmalar 1. kalite portakalı Rusya ve Avrupa ülkelerine gönderdiklerini, 2. kalite portakalı ise Orta Doğu ülkelerine gönderdiklerini ifade ederken Irak ve Suriye'nin kalite konusunda seçici olmadıklarını da belirtmişlerdir.

Çizelge 3. Firmaların hedef pazar seçimi ile gelir ilişkisi

\begin{tabular}{|c|c|c|c|c|c|c|c|c|c|c|c|}
\hline \multirow{2}{*}{$\begin{array}{l}\text { Hedef } \\
\text { Pazar }\end{array}$} & \multicolumn{2}{|c|}{1 milyon $\$ a z$} & \multicolumn{4}{|c|}{$1-4.99$ milyon $\$$} & \multirow{2}{*}{$\begin{array}{l}5-9.99 \text { milyon } \$ \\
G\end{array}$} & \multirow{2}{*}{$\begin{array}{c}10-14.99 \text { milyon } \$ \\
\mathrm{~B}\end{array}$} & \multicolumn{2}{|c|}{15 milyon $\$$ üzeri } & \multirow[t]{2}{*}{ Toplam } \\
\hline & $\mathrm{G}$ & $\mathrm{B}$ & $\mathrm{G}$ & $\mathrm{B}$ & $\mathrm{G}$ & $\mathrm{B}$ & & & $\mathrm{G}$ & $\mathrm{B}$ & \\
\hline Yurt dişı & 3 & 5.5 & 6 & 6.1 & 4 & 4.1 & 3 & 3.4 & 12 & 8.9 & 28 \\
\hline Yurtdışı ve Yurtiçi & 5 & 2.5 & 3 & 2.9 & 2 & 1.9 & 2 & 1.6 & 1 & 4.1 & 13 \\
\hline Toplam & 8 & 8.0 & 9 & 9.0 & 6 & 6.0 & 5 & 5.0 & 13 & 13.0 & 41 \\
\hline
\end{tabular}

Anlamlılık Değeri (Sig.): 0.129; $\mathrm{X}^{2}=7.143 ; \mathrm{df}=4$; G: Gözlenen; B: Beklenen

$\mathrm{H}_{0}$ : Firmaların hedef pazar seçimi ile firmanın yıllık gelir arasında ilişki vardır.

$\mathrm{H}_{1}$ : Firmaların hedef pazar seçimi ile firmanın yıllık gelir arasında ilişki yoktur. 
Dış pazarlardaki rekabetin durumunun önemli olduğunu belirten işletmeler (\%22.9) için Rusya piyasasında rekabetin yoğun olduğunu çok satıcının bulunduğunu ifade etmektedirler. $\mathrm{Bu}$ durum dezavantaj görünmesine rağmen en fazla kazanç sağlayan da Rusya piyasasıdır. Rusya, Türkiye'ye mesafesinin az olması ulaşım maliyetlerini azaltmakta ve belli dönemlerde yapılan siyasi ve politik desteklemelerle olumlu sonuçlar elde edilebilir. Hatay'da bulunan ihracat firmaları için işletme kaynaklarının sinırlılığı önem arz etmemektedir. Hatay ilinde portakal ihracatı yapan firmaların dış pazarlarda en çok dikkat ettikleri diğer unsurlar; maliyetin az olması, nakit ödeme, karşılıklı ilişkilerin güvene dayalı olması, mesafenin kısa olması, kur farkı az olan yerler veya kurun istikrarlı olduğu ülkeler, temsilciliklerinin bulunması ve belge ve prosedürün az olduğu yerler şeklinde sıralanabilir. Firmalar daha çok ürünlerin alımında daha az seçici olan, ödemede sıkıntının yaşanmadığı, mesafenin yakınlığı nedeniyle maliyetin azaldığı ve ikili ilişkilerin iyi olduğu Ortadoğu ülkelerine yönelimleri daha fazladır. Fakat neredeyse tüm firmaların Rusya pazarına yönelmeleri tamamen aksine bir durumu gözetmektedir. Rusya pazarında rekabet yoğun, belge ve prosedürün fazla olduğu, ülkenin ayrıntılı analizler istemesi, kaliteli ürün alımı yapması ve mesafenin fazla olması gibi aksi durumlar olmasına rağmen karın yüksek olması firmaları bu pazara yöneltmektedir.

İşletmelerin gelecekte yeni pazarlara açılma durumları ele alındığında \%65.9'u gelecek yıllarda mevcut pazarlarının dışına çıkmak istememektedirler. Yeni pazarlara girmekte tereddüt etmeleri piyasalardaki istikrarsızlık nedeniyle mevcut pazarlarını korumak ve ayakta kalma politikası izlemektedirler. Aynı zamanda yeni pazarlardaki müşterilere güvensizlikleri yeni atılımları engellemektedir. Yeni pazarlardaki rekabetin yoğunluğu, ulaşım ve iş̧̧ilik maliyetlerinin fazla olması yeni adımları zorlaştırıcı faktörler arasında görülmektedir. Demir'in 2009 yılında yaptığı çalışmada, yeni pazar aramak yerine komşu ülkelerle olan ticaretin artırılmasını gerektiği ortaya konulmuştur. Buna göre araştırma, çalışmamız sonuçları ile benzerlik göstermekte ve işletmeler pazar paylarını korumak istemektedir. İşletmelerin \%34.1'i gelecek yıllarda yeni pazarlara girmeyi istemektedirler. Rusya pazarma girmek istemelerinin en avantajlı yanı ülkenin piyasa kurundaki istikrardır, dezavantajı ise yoğun bir rekabet ortamı bulunmaktadır. Yeni pazar arayışındaki işletmeler için, Ukrayna ve Gürcistan piyasasında ürünleri daha yüksek fiyatta satma imkanı bulabilmektedir. İngiltere piyasasını ekonomik güç göstergesi gibi gören firmalar bu durumun firma prestijini arttırdiğını düşünmektedir. Arap ülkelerine ihracat yapmayı düşünen firmalar, Arapça bilmenin avantajı ile iletişimde sorun yaşamayacağını ve taşıma maliyetlerinin mesafeden dolayı daha az olması ile avantajlı olacaklarını belirtmektedirler. Polonya piyasasına girmek isteyen firmalar ise ülkenin istediği kalitedeki ürüne sahip olduklarını ve şartlarını sağlayabilecek özelliklere sahip oldukları konusunda hem fikirdirler, fakat bir girişim bulunmamaktadırlar.

\section{Ürün Stratejisi}

İşletmelerin ihracata konu olan ürünleri temin şekli $\% 80.5$ 'i direkt üreticiden almayı tercih etmektedir. Firmaların direkt üreticilerden almayı tercih etmelerindeki nedenlerinin en önemlisi aracı maliyetlerini en aza indirgemek ve böylelikle maliyetleri azaltmaktır. Bu sayede üreticiye de destek sağlanmaktadır. Zenginoğlu'nun (2007) yaptığı çalışmada, Türkiye genelindeki ihracat firmalarının $\% 83.7 \quad \operatorname{sinin} \quad$ üreticiden, \%8.1'inin hal/komisyonculardan ve \%4.1'inin ise kendi üretiminden temin ettiği sonucuna varmıştır. Böylece Zenginoğlu'nun çalışmasıyla benzerlik göstermektedir. Temin edilen ürünün alıcıya ulaşana kadar uğradığı ürün kaybı Hatay'da \%10-15 oranında bulunmuştur. Firmaların ürün kayıpları yaşadığı durumlarda başvurdukları yöntem, 41 firmanın 24 'ü $(\% 58,50)$ ürünü imha etmeyi tercih ederken, 17'si (\%41.50) ürünleri iç piyasada değerlendirmeyi uygun bulmaktadır.

Dış ticarete konu olan ürünün ambalaj şekli ülkenin isteğine, iklim şartlarına, mesafenin uzunluğuna ve taşıma şekline göre değişim göstermektedir. Hatay'daki işletmeler arasında \%95.1 gibi büyük bir oranda plastik kutu kullanılmaktadır. Tahta ve karton kutu kullanımı ise \%75.6 oranındadır. Zenginoğlu'nun (2007) yaptığı çalışmaya göre, Türkiye'de işletmeler tarafindan en fazla kullanılan ambalaj materyali karton kutu iken, en az kullanılan plastik kasa sonucunu ortaya koymuştur. Fakat Hatay ilinde yapılan çalışmaya göre en çok tercih edilen ambalaj materyali plastik kasa olarak bulunmuş ve Zenginoğlu'nun (2007) çalışmasıyla benzerlik bulunmamaktadır. Alipour ve ark.'nın (2013) yaptığı çalışmada, tahta ve plastik ambalajlama kullanıldığ sonucuna varmışlardır ve elde edilen bulgulara göre bu çalışma ile benzerlik göstermektedir. Ambalaj türünün seçiminde önemli olan faktörler Çizelge 4'te belirtilmiştir. Ambalaj seçiminde en önemli faktörler maliyet (\%44), alıcinın talebi (\%39) ve ürünlerin etkileşimini azaltmak (\%17) şeklindedir. Ambalaj türü ülkeden ülkeye farklılık göstermektedir. Karton kutu pahalı ve ürünler arası etkileşimi en az olan ambalaj türüdür. Karton kutu ambalaj türünü seçen ülkelerin ekonomilerinin iyi olduğu söylenebilir (Çizelge 4). Hatay'da portakal ihracatı yapan işletmelerle yapılan görüşmeler sonucunda \%53.6'sı ürün konumlandırması yapmaktadır. Firmalar yaptıkları konumlandırma şekillerine göre \%59'u ürünlerini hem 
yemelik hem de sıkmalık portakal olarak ayırmaktadır. Mamul özelliklerine göre yapılan konumlandırma ile ülke seçiminde bulunmasına da alıcı sınıflarına göre konumlandırma yaptığı sonucu çıkartılabilir. Buna göre sıkmalık portakal ihracatı daha çok Irak, Makedonya ve Dubai'ye yapılmaktadır. Fakat firmalar sikmalık portakalın ihracata uygun olmadığını ve bunun için iç piyasaya sunulması gerektiği konusunda hem fikirdirler.

Çizelge 4. İşletmelerin ambalaj seçimini etkileyen faktörler

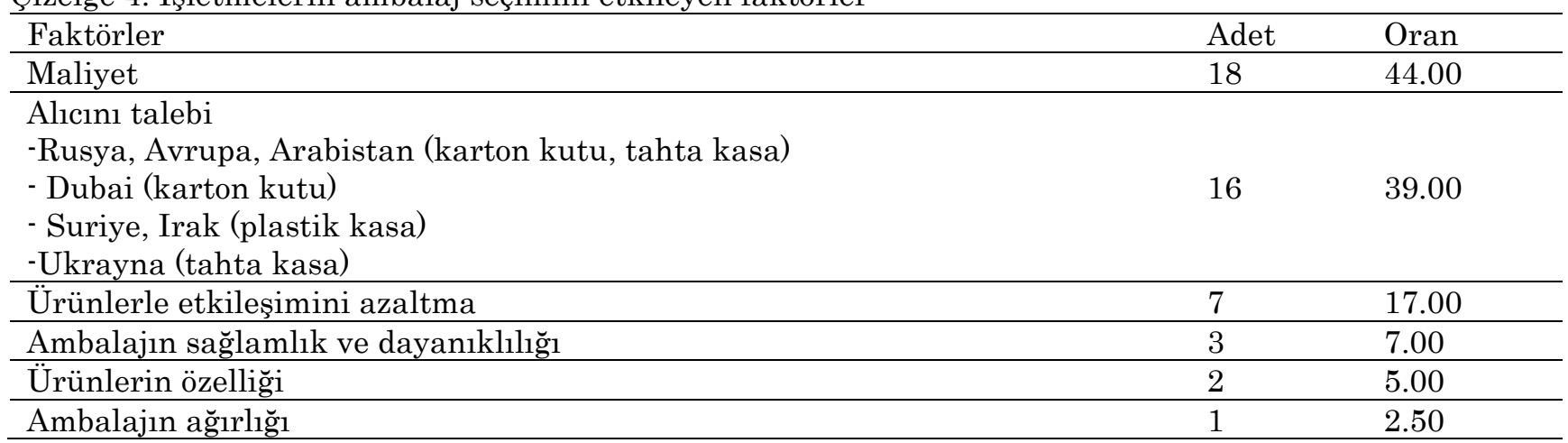

*Birden fazla şı işaretlenmiş olup, değerlendirme her bir faktör için 41 firma baz alınarak oran hesaplanmıştır.

\section{Marka ve Markalama Stratejisi}

Markalaşma bir firmanın stratejik yatırımlarından biridir. Günümüzde markalaşma rekabet koşullarında önemli bir konuma gelmektedir. Alıcının ürünü almasında psikolojik bağımlılık yaratması, markanın yarattığı imaj ve bu koşullar altında tüketicinin ödemeye gönüllü olduğu yüksek fiyat rekabet koşullarında markalaşmış ürünleri bir adım öne çıkarmaktadır. Bu nedenle markalaşma kısa vadeli bir yatırım değil, uzun vadede rekabetçiliğin göstergesidir (Alkin ve ark. 2007, Koyuncugil ve Özgülbaş 2014).

Hatay'da ihracatçı firmalar yurtdışı pazarlarında marka kullanımının önemli olduğunu belirtmekte ve \%95’i pazarlarda marka kullanmaktadır. Görüşülen firmaların \%95’i yurtdışı pazarında ferdi (bireysel) marka türünü kullanırken, \%2.5’i aracı firmaların markasını ve geri kalan kısım ise ortak marka kullanmayı tercih etmektedir. Firmaların \%95’i yurtdışı pazarlarda ürünlerinde Türk malı olduğunu belirten işaret kullanmaktadır. Türk malı olduğunu belirten 37 firmanın \%54'ü yurtdışı pazarlarda satışları çok etkilediğini belirtmiştir. Bu etkinin Irak pazarında kalite göstergesi olarak algıladığını, Rusya pazarında ise bazı dönemlerde sıkıntı yarattığı ortaya konulmuştur. Fakat genel itibariyle satışlara olumlu yönde yansıdığı düşünülmektedir.

\section{Fiyatlandirma Stratejisi}

İşletmenin uluslararası pazarlarda fiyat belirlemede aldığ 1 doğru karar, firmanın hedefine ulaşmasına sağlar (Akat 2012). Bu nedenle firma hedefini doğru belirlemeli ve işletme politikalarını aracı olarak kullanmalıdır. İşletmenin hedefleri; karlılık, işletmenin ayakta kalabilmesi, bir pazarı hızla ele geçirmek, rekabetin yoğun olduğu pazarlarda pazar payını korumak, yüksek kalite imajı yaratmak ve korumak, aranan marka olmak ve lider olmak şeklinde sıralanabilir. İşletmenin ilk hedefi masrafları azaltarak kar elde edebilmektir.

Yapılan anket sonuçlarına göre Hatay'da işletmelerin yıllık masraf unsurları Çizelge 5'teki gibidir. İhracatta en fazla maliyet unsurları; yurtiçi taşıma ve ihracat işlemleri (\%58.5), ihraç pazarındaki gümrük ve dağıtım maliyetleri (\%58.5), iş̧̧ilik masrafları (\%56.1) ve tarım ürünü maliyeti (\%53.7)'dir. Bu masraf unsurları yurtdışı pazarlarda rekabeti en çok etkileyen unsurlardır. Fiyat rekabetinde firmaların geri adımını engellemektedir. İhracat masrafları arasında en çok ürün alımı masrafları yer almaktadır. Girdi maliyetlerinin fazla olması fiyatları yükseltirken iş̧̧ilik masrafları da eklendiğinde yıllık ihracat masraflarının yarısından fazlasinı oluşturmaktadırlar.

İşletmelerin yurtdışı pazarlardaki öncelikli hedefi karlılık artışı ve pazar payını korumaktır. İşletmeler yurtdışı pazarlarda pazar payını artırmak yerine mevcut pazarını korumayı tercih etmektedirler. Böylece ayakta kalmaya devam edebilecek ve sürdürülebilirliğini sağlayacaktır (Çizelge 6). Elde edilen sonuçlar ışığında karını maksimize etmek isteyen firmaların yurtdışı pazarında \%46.1'i fiyatlarını piyasa fiyatlarına göre belirlerken, \%38.4'ü ise yüksek fiyat stratejisini benimsemişlerdir. Yüksek fiyat strateji benimseyen firmalar ürün imajı yaratarak en kaliteli ürünü sattıklarını düşünmektedirler.

Yüksek fiyat stratejisi uygulamak için belli bir pazar payına sahip ve markasına güven oluşturmuş işletmeler için uygun olduğu düşünülebilir. Pazar payını korumak isteyen firmalar ise piyasadaki fiyatlara göre fiyatlandırma yaparak pazarda kalmayı tercih etmektedirler. İsletmeler ihracat yapacakları ülkeleri ve müşterileri ihracat sezonu öncesinde ya da sezon içerisinde gelen talepler doğrultusunda belirleyebilmektedir. 
Çizelge 5. İşletmelerin yıllık ihracat masrafları

\begin{tabular}{ll}
\hline Masraf Unsurları & Toplam Masraf İçindeki Oran (\%) \\
\hline Ürün alımı veya üretim masrafı & $40-50$ \\
\hline İşilik masrafı & $20-30$ \\
\hline Taşıma & $10-15$ \\
\hline Ürün kayıpları/zararları & $10-15$ \\
\hline Depolama & $5-10$ \\
\hline Ambalajlama & $5-10$ \\
\hline Vergi & $5-7$ \\
\hline Belge masrafı & $3-5$ \\
\hline Reklam & $3-5$ \\
\hline Büro masrafları & $3-5$ \\
\hline Görünmeyen masraflar (cezalar, yükleme boşaltma ücretleri) & $3-5$ \\
\hline Ürün veya taşıma sigortası & $2-3$ \\
\hline
\end{tabular}

Çizelge 6. Firmaların ürün fiyatı belirlemedeki etkili hedefleri

\begin{tabular}{lll}
\hline Firmaların Ulaşmak İstedikleri Hedefleri & Adet & Oran \\
\hline Karı maksimize etmek & 26 & 63.4 \\
\hline Pazar payını korumak & 24 & 58.5 \\
\hline Ayakta kalabilmek & 9 & 21.9 \\
\hline Pazar payını artırmak & 4 & 9.8 \\
\hline Markalarını tanıtmak & 3 & 7.3 \\
\hline Rekabeti ortadan kaldırmak & 2 & 4.9
\end{tabular}

*Birden fazla şık işaretlenmiş olup, değerlendirme her bir faktör için 41 firma baz alınarak oran hesaplanmıştır.

Sezon öncesi bağlantılara göre ihracat yapmanın avantajı ve dezavantajı bulunmaktadır. İhracat sezonu içerisinde müşterileri ve ürünlerini pazarlama imkanı daha kolay bulurken, sezon içinde fiyatların düşmesi dezavantaj yaratabilir. $\mathrm{Bu}$ durumda firmaların ihracat sezonu içerisinde veya öncesinde yapılan bağlantılarının piyasaya giriş stratejilerine etkisi Çizelge 7'de sunulmuştur.

Firmaların ihracat şeklinin piyasaya ilk giriş fiyat stratejisi üzerinde istatistiki açıdan anlamlı bir sonuç bulunamamış ve bu durumda uygulanan analiz üzerine $\% 5$ anlamlllık düzeyinde $\mathrm{H}_{0}$ hipotezi reddedilmektedir. Çizelge 7'deki sonuçlara göre Hatay'daki ihracatçı firmalar ihracat sezonu süresi içinde gelen taleplere göre ve piyasada belirlenen fiyat seviyesine yani piyasa fiyatına göre ihracatlarını şekillendirmektedirler. İncelenen işletmelerde ihracat fiyatlarının belirlemesinde etkili olan unsurların etki derecelerinin belirlenmesi istenmiş olup 5'li Likert Ölçeği ile kullanılarak sonuçlar ortaya konulmuştur. $\mathrm{Bu}$ sonuçlara göre; fiyat belirlemede en etkili unsur ürün kalitesi, imajı 4.83 ölçek ortalaması ile ilk sırada yer almaktadır.

Diğer öncelikli etkenler ise; 4.39 ile rakip ülke fiyatları ve devlet politikaları, 4.05 ortalama ile müşteri isteği ve 3.93 ortalama ile maliyetler şeklinde sıralanabilir. Zenginoğlu (2007) yaptığı çalışmasında 3’lü Likert Ölçeği kullanarak bulunduğu sonuçlar şu şekildedir.

İhraç fiyatını belirlenmesinde etki eden faktörlerin başında maliyetler (2.53), müşteri talebi (2.30), rakip ülke fiyatları (2.07), ürün kalitesi (1.31), yerli ihracatçı fiyatları (1.10) ve aracı firmalar (1.00) şeklinde sıralanmaktadır. $\mathrm{Bu}$ çalışmaya göre öncelik sıralamalarının sonuçlarına göre sonuçlar arasında paralellik bulunmamaktadir.

Çizelge 7. İhracat döneminde zamanlamanın piyasaya giriş stratejisi üzerine etkisi

\begin{tabular}{llllllll}
\hline \multirow{2}{*}{ İhracat şekli } & \multicolumn{2}{l}{ Yüksek fiyat stratejisi } & \multicolumn{2}{l}{ Düşük Fiyat Stratejisi } & $\begin{array}{l}\text { Piyasa } \\
\text { Fiyatı }\end{array}$ & \multirow{2}{*}{ Toplam } \\
\cline { 2 - 7 } & $\mathrm{G}$ & $\mathrm{B}$ & $\mathrm{G}$ & $\mathrm{B}$ & $\mathrm{G}$ & $\mathrm{B}$ & \\
\hline Sezon Öncesi & 4 & 2.6 & 4 & 2.4 & 1 & 4.0 & 9 \\
\hline Sezonda Talep & 6 & 7.6 & 6 & 7.0 & 14 & 11.4 & 26 \\
\hline Her ikisi de & 2 & 1.8 & 1 & 1.6 & 3 & 2.6 & 6 \\
\hline Toplam & 12 & 12.0 & 11 & 11.0 & 18 & 18.0 & 41 \\
\hline An & 0 & &
\end{tabular}

Anlamlılık Değeri (Sig.): 0.255; X²=5.332;df=4; G: Gözlenen; B: Beklenen

$\mathrm{H}_{0}$ : Firmaların ihracat sezonu ile piyasaya giriş stratejileri arasında ilişki vardır.

$\mathrm{H}_{1}$ : Firmaların ihracat sezonu ile piyasaya giriş stratejileri arasında ilişki yoktur. 
Pazarlama anlayışına göre müşteri talebi ilk sıralarda olması gerekirken, Hatay ilindeki işletmeler üretime yönelmiştir. Ürünün ne kadar kaliteli olursa olsun talep yoksa ürünün satışı da olmayacaktır. Bu nedenle işletmeler önceliklerini değiştirmeli müşteri odaklı çalışmalıdır.

\section{İşletmelerin Taşıma Şekilleri}

İşletmeler ihracata konu olan ürünlerin üreticiden alıcıya teslim etme sürecini etkin bir şekilde planlamalıdır. Dağıtım kanalında yer alan aracı kuruşların belirlenmesi, ürünün istenilen noktaya taşınmasında aracı kuruluşların etkinliği gibi fiziksel taşıma hareketleri içinde yer almaktadır. Firmaların izlediği taşıma faaliyetleri Şekil 1' de belirtildiği gibidir. Bahçeden paketleme evine olan taşıma işlemi firmalar tarafindan kendi imkanları ile yapılmaktadır. İşletmelerin \%76'sında paketleme evinden alıcıya teslim kendi firması tarafindan yapılmaktadır. İşletmelerin uluslararası pazarlara taşıma şekli ise Şekil 2 ile gösterilmiştir.

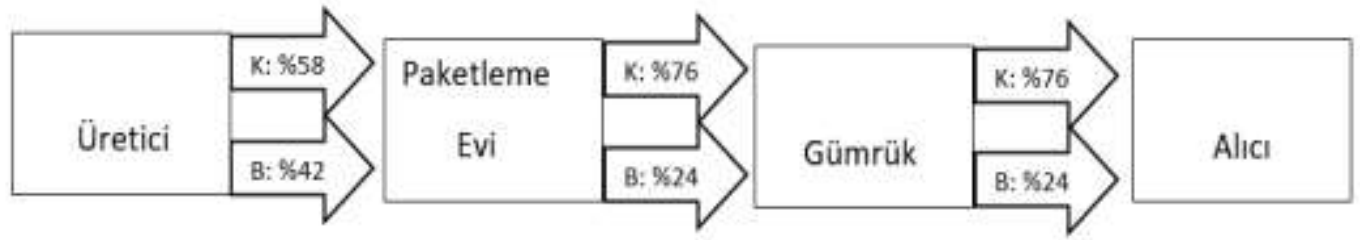

K: Kendi firması; B: Bağımsız İhracatçı Firma

Şekil 1. Firmaların taşıma faaliyetleri

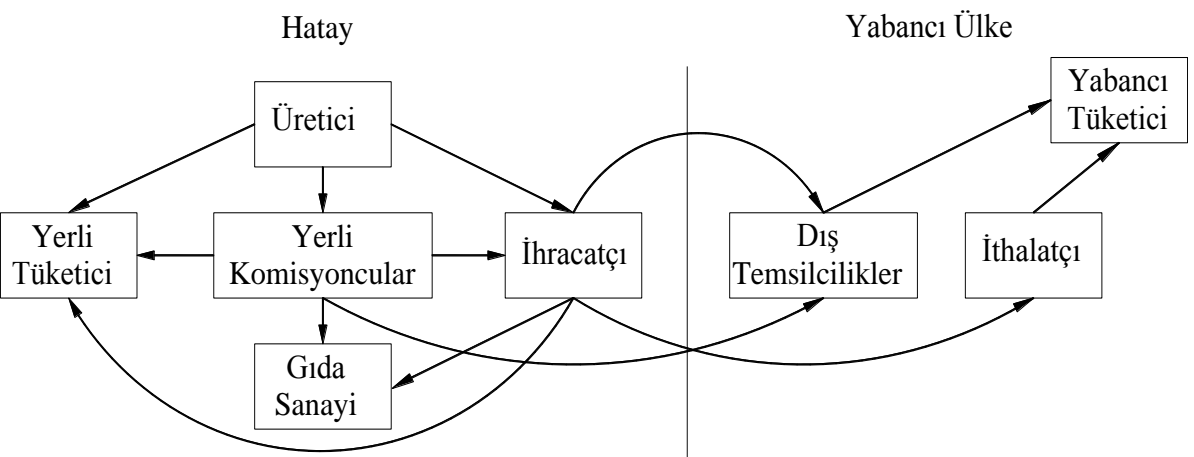

Şekil 2. Hatay'da işletmelerin uluslararası pazarlara taşıma şekli

Portakal üreticileri yerli komisyoncuya ve ihracatçı işletmelere satı̧̧ yapabileceği gibi iç piyasaya da ürün sunabilmektedir. Yerli komisyoncular aldığı ürünü ihracatçı işletmelere pazarlamakta ya da işletmecileri aracı kullanmadan doğrudan yurtdışı pazarlarına gönderilmektedir. Ayrıca yurtdışı pazarlarına uygun bulunmayan veya talep edilmeyen ürünleri iç piyasaya sunarak değerlendirmektedirler. İhracatçı işletmeler ürünlerini kalitelerine göre sinıflandırdıktan sonra ihracata uygun olmayan ürünleri iç piyasaya sunabilmekte ya da gıda sanayiye gönderebilmektedir. Ayrıca ihracatçılar direk dış pazara satabileceği gibi dış komisyoncuları aracı olarak kullanarak dış pazarlara ulaşabilmektedir. Dış pazarlarda yabancı tüketiciye ithalatçı işletme tarafından sunabileceği gibi dış temsilciliklerden de ürünler tüketiciye ulaştırılabilir.

Taşımacılık karayolu, denizyolu ve havayolu ile sağlanmaktadır. Havayolu taşımacılığı maliyetli olması sebebiyle tercih edilmemektedir. Hatay'da ihracatçıların tamamı karayolu taşımacılığı kullanmaktadır. Karayolu taşımacılığının en fazla kullanıldığı ülkeler ve işletmeler tarafindan tercih edilme payları ile sirasıyla; Irak (\%73), Rusya (\%19), Romanya (\%17) ve Suriye (\%12)'dir. Hatay, Türkiye'de İstanbul'dan sonra en büyük araç filosuna sahip ildir ve 145 ülkeye 8.225 adet taşıt ile taşıma yapmaktadır. İldeki ihracat ağırlıklı olarak Ortadoğu ve Avrupa'ya yöneliktir. İldeki ihracat Suriye krizi nedeniyle aksamaya uğramış, karayolu transit geçiş yolu ve pazarının kapanması yaklaşık 45-50 milyar \$'lık kayba neden olmuştur. Bu nedenle Ortadoğu ihracatı Türkiye-Mısır, Türkiye-İsrail ve Türkiye-Lübnan arasında yapılan Ro-Ro seferleri ile sağlanmaktadır. Ro-Ro taşıma, tekerlekli araç taşımada kullanılan gemidir ve karayolu taşımacılığında mesafeyi kısaltmaktadır. 2012 yılında Suriye krizi ile başlayan bu taşımacılık şeklinde 2012 yılında tır başına $1000 \$$ 'lık devlet desteği ile ihracat kazandırılmış, fakat bu destek uzun sürmemiş 2013 yılında 500\$'a düşürülerek, 14 Ağustos 2013'te ise tamamen kaldırılmıştır. Ayrıca Hatay'da Ro-Ro şirketlerinin 
sefer başına uyguladıkları fiyatlardaki tutarsızlık, sefer günlerindeki düzensizlik, liman altyapısındaki eksiklikler, 17-18 gün süren gidiş geliş seferlerinin 5560 güne çıkması ve bu nedenlerde tarımsal ürün kayıplarındaki artış firmaların pazar kaybetmesine yol açmıştır. Desteğin kaldırılması ve Ro-Ro şirketlerin olumsuzlukları ile Irak, İran, Arabistan, Mısır ve Lübnan ihracatında azalma gözlenmiştir (Koyuncugil ve Özgülbaş 2014). Portakal ihracatı yapan işletmelerde Ortadoğu ticaretinde Ro-Ro taşımacılığı kullanılmaktadır. Fakat yaşanılan sorunlar portakal ihracatçılarını da etkilemiştir.

\section{Tutundurma Stratejileri}

Tutundurma, 'tüketicileri bir mal, hizmet, marka veya kuruluşun varlığından haberdar etmek, o malal hizmete, markaya ve kuruluşa karşı olumlu bir tavır takınmaya özendirmek amacıyla yapılan bilinçli, programlanmış ve koordineli faaliyetlerden oluşan bir iletişim sürecidir (Öztürk 1978, Akat 2012). Tutundurma faaliyetleri satış artırmaya yönelik yapılan çalışmalardır. Tutundurma çalışmalarında en önemli faaliyet reklamdır. Günümüzde teknolojinin kullanımı ile reklam faaliyetleri internet kaynaklı olmaktadır. Bunun dışında televizyon, sergiler, fuarlar, bilboard reklamları da tercih edilmektedir. Diğer tutundurma faaliyetleri ise; ilanlar, yüz yüze satış, promosyon ve halkla ilişkilerdir. Hatay'daki portakal ihracatı yapan firmaların \%9,8'i tanitım faaliyetinde bulunduğunu ve bu faaliyetlerinde televizyon ve internete verilen reklamlardan oluştuğu sonucuna varılmıştır. Kalan firmaların \%90,2'si yani neredeyse tamamına yakını yurtdışında tanıtım faaliyetlerinde bulunmamaktadir. Bu faaliyetlerin az olmasının en büyük sebebi işletmeler tanıtım faaliyetlerini masraf olarak düşünmesidir. Geri bildirimi çabuk olmayan bir faaliyet olabilir ama işletmelerin satışlarını artırmada önemli bir unsurdur. Ticarette yapilan promosyon uygulamaları da tanıtım faaliyetlerinin bir koludur. İldeki ihracatçı firmaların sadece \%19.5'i promosyon uygulamaktadır. $\mathrm{Bu}$ uygulama fiyat indirimi şeklinde gerçekleşmektedir. Bu firmaların uyguladıkları fiyat indiriminin satışları nasıl etkilediği sorulduğunda $\% 50$ 'si etkilediğini, \%25'i ise etkilemediğini belirtirken, geriye kalan kısmı ise az etkilediğini belirtmiştir.

\section{İşletmelerin İhracatta Karşılaştıkları Sorunlar}

Ambalajlamanın yurt dışı pazarlarda tüketicinin tercihini etkileyen bir unsur olduğu birçok çalışma ile de desteklenmiştir. Firmalar ürünlerini ambalajlama şekillerine önem vermekte ve ihraç edeceği ülkenin isteklerine göre değişikliklerde bulunmaktadır. Uygun ambalajlama tesisinin bulunmaması, ambalajlamanın türüne veya şekline göre maliyetin artması yaşanılan sorunlar arasında yer almaktadır. Bu bilgiler ışığında, göre firmaların \%80’i ürün ambalajlama konusunda sorun yaşamamaktadır. Geriye kalan kısım ise uygun ambalaj tesisi olmadığından, ambalajlamanın masraflı olması ve işçilik hatalarının maliyeti artırması konusunda sıkıntı yaşadıklarını belirtmişlerdir.

Depolama firmalar için hem masraflı hem de sorunların yaşandığı önemli bir maliyet unsurudur. Tarım ürünlerinin mevsimlik olması, toplandıktan sonra soğuk hava depolarında saklanması, hasattan sonra olgunlaşmaya birakılan ürünlerin depolama sırasında ürün kaybına uğramaktadır. Anket sonuçlarına göre, Hatay'daki portakal ihracatı yapan firmaların \%49'i depolama yapmaktadır. Depolama yapan 20 firmanın \%30’u depo yüklügünün yeterli olmaması ve karışık depolama nedeniyle ürün kaybı veya kalite kaybı yaşadığını belirtmektedir. Kalite ve ürün kaybı yaşanan ürünler daha çok ya iç piyasaya verilmekte ya da atılmaktadır.

Taşıma ihracatta en önemli kısımdır. Ürünlerin donanımlı araçlarla taşınması ve personelin kaynaklanan hatalar ürün kaybına yol açabileceği gibi maliyeti de yükseltmektedir. Yapılan anketler sonucunda portakal ihracatçısı firmaların \%60'1 taşımada sorunlar yaşamaktadır. $\mathrm{Bu}$ firmalar içerisinde taşıma işlemlerini kendi yapmasına karşın sorun yaşayan firma \%89 oranındadır. Taşımada en çok karşlaşılan sorunun araç sayısı ve kapasitesindeki yetersizlik (\%52) ve eğitimli personel eksikliği (\%44) olduğu gösterilmektedir. Araç sayısındaki yetersizlik özellikle ihracatın yoğun olduğu zamanlarda gelir kaybına yol açmakta talep olmasina rağmen ürün gönderilememektedir. Diğer bir sorun ise araçların teknik donanımlarından kaynaklı olarak ürün kaybının yaşanmasıdır.

Dış ticarete ülke içinde yapılması gereken işlemler ve aniden gelişen olaylar karşısında yapılması gerekenler vardır. Ülke içinde resmi kurumlar tarafından yapılması/alınması gereken belgelerin ve prosedürlerin fazla olması firmalarda (\%34) sorun yaratmaktadır. $\mathrm{Bu}$ işlemler zaman kaybı olarak nitelendirilmektedir. Ani gelişen olaylar ise ülkelerarası siyasi ilişkilerin ihracatta yarattığı sorunlardır. Özellikle Rusya'nın Türk ihracatçılardan istediği analizlerin sebebi, ürünleri almamak için olduğunu iddia etmektedirler. Bu durum karşısında ihracatçlar sorun yaşamakta ve ürünlerini geri çekmek veya başka ülkelere göndermek zorunda kalmaktadır.

Devletin verdiği teşviklerin ve KDV'lerin ödenmesinde yaşanan aksaklıklar ihracatı etkilemektedir. Verilen teşviklerin az olması ve zamanında ödenmemesi ihracatçıların yaşadığı sorunlardan sadece biridir.

Türkiye'deki piyasalarda yaşanan ani dalgalanmalar ve piyasalardaki istikrarsızlıklar ihracatçıların yaşadığı bir diğer sorundur. Para piyasasının bu kadar belirsiz olması kar ve zarar durumunu etkilemekte ve 
firmaların yeni pazarlara açılmasında ya da ihracat yapıldığında ileriyi görmelerinde sıkıntı yaşatmaktadır.

Girdi maliyetlerinin Türkiye'de yüksek olmasının dezavantajını, dış pazarlarda rakip ülke fiyatları karşısında daha belirgin hale gelmektedir. Örneğin İspanya'da verilen teşvikler nedeniyle ürün fiyatlarının düşük olması, Türk ihracatçıları rekabette etkilemektedir. İspanya fiyatlarının altına veya eşit seviyeye ulaşamamaları sebebiyle sıkıntı yaşanmaktadır. $\mathrm{Bu}$ nedenle işletmeler, İspanya ihracatçılarının piyasaya girmesiyle Türkiye portakallarına olan rağbetin azaldığını gözlemlemişlerdir.

İhracat yapılan ülkelerde yaşanan sorunlar Türkiye'de yaşanan sorunlarla benzerlik göstermektedir. Özellikle ülkeler arası ikili ilişkiler, resmi prosedürlerin fazlalığı ve piyasalardaki dengesizlik şeklinde sıralanabilir. Türkiye ile ihracat yapılan ülkeler arasında kalan ülkelerin gümrüklerinde yaşanan sıkıntılar; gümrüklerde bekleme sürelerinin uzaması, fazla gümrük vergisinin ödenmesi, Romanya'ya yapılan ihracatta Bulgaristan gümrügünde personelden kaynaklanan sorunların yanı sıra Bulgar gümrüğünde $360 £$ analiz parasının alınması ve zaman kaybı yaşanmasina sebep olmaktadır. Ayrıca Avrupa kapısında ürünlere analiz yapılması ve sorun çıkması halinde geçişe izin verilmemesi şeklinde sıralanabilir.

\section{SONUÇLAR}

Yapılan anket sonuçlarına göre, işletmelerin \%70’i sadece ihracat yapmaktadır. İldeki firmaların uluslararası pazarlarda bulunma süreleri ortalama olarak 17 yıldır. Firmalar dış ticarette genellikle kendi çabaları (\%48) ve ortak girişim (\%31.7) ile başlamayı tercih etmişler ve uzun süreler sonunda hala ihracata devam etmektedirler. Hatay portakal ihracat piyasasını 5 büyük firmanın şekillendirdiği bu çalışma ile belirlenmiş̧tir. İşletmelerin dış pazarlarda sunulan ürünleri direk üreticiden almayı tercih etmektedirler. $\mathrm{Bu}$ alım hem üreticiye destek olmak hem de araciların yarattığı fiyat artışından kaçınarak maliyetin düşmesini sağlamaktadır.

İhracatı artırmak ve ekonomiye katkı sağlamak amacıyla devlet tarafından ihracatçı firmalara DFİF (Destekleme ve Fiyat İstikrar Fonu) adı altında destek fonu oluşturularak yapılan teşvik modelidir. Hatay ilinde portakal ihracatçısı firmaların \%100'ü ihraç ettikleri ton başına ürüne 150 TL destek almaktadırlar. $\mathrm{Bu}$ durumda anketten elde edilen bilgilere göre Hatay'da 2014 yll verilerine göre toplam 488.045 ton portakal ihracatı yapıldığına göre 73.206.744 TL destek alındığı sonucu ortaya çıkmaktadır.

İşletmelerin büyük çoğunluğunun dış pazarlarda temsilciliklerinin bulunduğu gözlemlenmiştir. Ürün kalitesi, fiyat bilgileri, ülkenin pazar yapısı ve talepler gibi bilgiler dıs pazardaki temsilciliklerinin deneyim ve bilgisine birakılarak sürdürülmektedir.

Küreselleşmenin etkisiyle artık birçok ürünün elde edilebilirliği kolaylaşmaktadır. Bu nedenle ürünün satışında tutundurma faaliyetleri ile ürünün diğer benzer ürünlerden daha fazla satışının sağlanması konusunda çalışmalar gelişmektedir. Benzer ürünlerden bir adım öne geçmek adına her ülkenin ekonomik, demografik, sosyal ve kültürel yapısı incelenerek farklılaştırılmış pazar stratejileri kullanılmaktadır. Bu durumuna göre hareket eden Hatay portakal ihracatçıları yurtdışı pazarlarda ülkenin özellik ve isteklerine göre ürün stratejilerinin şekillendirmektedirler. Böylelikle işletmelerin \%100’ü farklılaştırılmış pazar stratejisini benimsedikleri sonucu ortaya konulmuştur.

Fiyatlandırma stratejisi pazarlama stratejinin en önemli kısımlarından biridir. Çünkü yoğun rekabetin olduğu pazarlarda firmalar yüksek veya düşük fiyat stratejisi uygulamanın avantaj görme ya da dezavantajını görme riski ile karşı karşıyadır. Yüksek fiyat stratejisi muadili olmayan benzersiz bir ürün satıldığında, markalaşmış bir ürünün satışında ya da ürün imajı yaratılmak istendiğinde kullanılmaktadır. $\mathrm{Bu}$ strateji yüksek kar getirme avantajına sahipken, istenilen imajin yaratılamaması üzerine talep edilmeme riski de bulunmaktadır. Düşük fiyat stratejisinde ise; rekabet ortamında firma hedeflediği miktarda ürünü satabilir fakat hedeflediği kara ulaşamayabilir. Düşük fiyat stratejisinin kullanılmasının altında yatan algı piyasada yer edinmek ya da varlığını sürdürmek adına yapılmaktadır. Bu iki durum işletmeler için avantaj sağlayabilir ya da dezavantaja dönüşebilir. Hatay'daki portakal ihracatçıları ise çoğunlukla piyasada oluşan fiyatlara göre fiyatlandırmayı belirledikleri ortaya konulmuştur. $\mathrm{Bu}$ nedenle fiyatlarında büyük oranlarda artış ya da azalış gözlenmediğinden satışlarını etkileyecek ölçüde promosyonlara genellikle başvurmamaktadırlar.

Hatay'da portakal ihracatı yapan işletmeler mevcut pazarlarını koruma amacı ile yeni pazarlara yönelmemektedirler. Yeni pazar firsatları işletmelerin pazar araştırması yapmaması ve piyasalara olan güvensizlikleri nedeniyle kaçırılmaktadır. Bu nedenle işletmeler pazar araştırma konusunda teşvik edilmeli veya yeni bağlantılar ihracatçı birliklerinin yardımı ile kurulmalıdır. Para piyasalarındaki dengesizlikler nedeniyle ihracatçıların yurtdışı pazarlarda yaşadığı belirsizlikler, Türk Lirası'nın Dolar karşısında değerinin zamanla yitirmesi nedeniyle yeni pazarlara girmenin riskli olduğunu düşünmektedirler. İşletmelerin yeni pazar araştırmaları konusunda teşvik edilmesi ve yeni pazarlara giren işletmelerin riskini azaltmak adına ihracat destekleme miktarları 
artırılmalıdır. İhracat yapan işletmeler farklılaştırılmış pazar stratejilerini benimsemiş olmalarına rağmen, döviz kurlarındaki hareketlilik ve Türk Lirasının uğradığı değer kaybı bunu engellemektedir.

Hatay'da portakal ihracatı yapan işletmelerin, uluslararası pazarlarda markalaşmasının ve tutundurma faaliyetlerine daha fazla önem verilmesinin gelirlerini artıracağı düşünülmektedir. Suudi Arabistan'da düzenlenen fuarlara katılmak yeterli olabilirken; Irak'ta ise televizyon reklamlarına ve fuarlara katılımlar tutundurma stratejilerinin uygulanmasında önemli yer tutacaktır. Ayrıca tutundurma faaliyetlerinden biri olan internet reklamlarına daha fazla önem verilerek daha fazla tüketiciye ulaşımı sağlanabilir.

Hatay'da ürün alıcıya teslim edilene kadar \%10-15 oranında ürün kaybına uğramaktadır. Bu kaybı en aza indirgemek için depolama şartlarının iyileştirilmesi, depolama kapasitelerinin artırılması, taşıma sırasında meydana gelen kayıpların azaltılması için de uygun donanımlı araçların kullanılması gerekmektedir.

Dış pazarlara sunulan ürünlerin alıcıya zamanında ulaşması, seçilen taşıma şekline göre ambalajlama seçimi, bozulma veya çürümeleri en aza indirecek donanımlı araçların kullanımı ve hızlı ulaşımın sağlanması taşımada izledikleri stratejinin temelini oluşturmaktadır. Hatay'daki portakal ihracatçılarının sınır kapılarına yakınlığı nedeniyle karayolunu tercih ederlerken, son zamanlarda sınır ülkede yaşanan savaş nedeniyle karayolu taşımacılığı sekteye uğrayarak denizyolu taşımacılığına yönelmişlerdir. Ancak, gemi taşımacılığına uygun ambalajlamanın yapılması nedeniyle nemden kaynaklanan bozulmalar, gemilerin ulaşımında yaşanan sıkıntılar, gemi taşımacılığının düzenli olarak yapılamaması, gemiye boşaltma ve yükleme maliyet sorunlarını da beraberinde getirmiştir. Taşımacılıkta yaşanan sorunlar ihracatı büyük oranda engellemektedir. Özellikle Hatay'da denizyolu taşımacılığında yaşanan sorunlar nedeniyle teslim süresinde sıkıntılar oluşurken, aynı zamanda alıcının güven ve beklentileri de sarsilmaktadir. $\mathrm{Bu}$ nedenle denizyolu taşımacılığında yaşanan sorunların minimum düzeye indirilmesi gerekmektedir. Bunun içinde düzenli zamanlarda gemi seferleri konulmall ve limanda bekletilme süreleri azaltılmalıdır. Devletin ülkelerle ikili ilişkilerini geliştirerek imtiyazların artırılması ihracat miktarının artırmasina destek olurken, Türkiye ekonomisine de katkı sağlayacaktır.

\section{TEŞEKKÜR}

$\mathrm{Bu}$ çalışma Hatay İlinin Portakal Üretimi ve Dış Ticarette İşletmelerin Pazarlama Stratejileri adlı yüksek lisans tezinden üretilmiştir.

\section{KAYNAKLAR}

Ahmed ZU, Craig CJ, Imad B,Tamar VH 2006. Firm Internationalization and Export Incentives From a Middle Eastern Perspective. Journal of Small Business And Enterprise Development, 13(4) : 660669

Akat Ö 2012. Uluslararası Pazarlama Karması ve Yönetimi MAI, Global Compact ve Örnek Olaylar, Gözden Geçirilmiş 8. Baskı, Ekin Kitabevi, Bursa. S.166.

Alipour H, Hoseinbeyki A, Johed M, Rahnama H, Sharifnia M 2013. A Review on Citrus Prodiction and Export Marketing Strategies in Mazandaran Province, Iran. Middle- East of Scientific Research 14 (10) : 1375-1380.

Alkin K, Bulu M, Kaya H 2007. Iller Arası Rekabet Endeksi: Türkiye'deki İllerin Rekabetçilik Seviyelerinin Göreceli Olarak Ölçülebilmesi İçin Bir Yaklaşım, İstanbul Ticaret Üniversitesi Sosyal Bilimler Dergisi, 11(2) : 221-235.

Anonim 2010. Turunçgil Durum Tahmin, Tarımsal Araştırma Enstitüsü, Kasım 2010. (Erişim Tarihi: 20.05.2016)

Anonymous 2013. Food and Agriculture Organization of the United Nations http://faostat3.fao.org (Erişim Tarihi: 27.04.2016).

Anonim 2013. Türkiye İstatistik Kurumu, http://www.tuik.gov.tr (Erişim Tarihi: 09.06.2016).

Anonim 2016. Türkiye Yaş Meyve-Sebze İhracatçı Birlikleri, http://www.yms.org.tr. (Erişim Tarihi: 29.09.2016).

Çalışkan Ş 2007. Eğitimin Getirisi (Uşak İli Örneği), Süleyman Demirel Üniversitesi İktisadi ve İdari Bilimler Fakültesi Dergisi, 12(2) : 235-252.

Demir S 2009. Dış Ticarette Etkin Pazarlama Stratejileri Üzerine Bir Saha Araştırması. Marmara Üniversitesi Sosyal Bilimler Enstitüsü Halkla İlişkiler Ana Bilim Dalı, Yüksek Lisans Tezi, , İstanbul, s.59-77

Güven N 2010. Adana İlinde Turunçgillerin Pazarlama Yapısı ve Sorunları, Çukurova Üniversitesi, Fen Bilimleri Enstitüsü, Tarım Ekonomisi Ana Bilim Dalı, Yüksek Lisans Tezi, Adana Sy.1-104

Karadeniz CF, Özkan B 2004. Antalya İlinde Turunçgil Meyvelerinin Dış Satımı ve Başlıca Sorunlarının İncelenmesi, Türkiye 6. Tarım Ekonomisi Kongresi, 16-18 Eylül 2004, Tokat.

Koyuncugil AS, Özgülbaş N 2014. 2013 Yılı Doğrudan Faaliyet Destek Programı Hatay İli İhracatı Araştırma Raporu, Hatay, Nisan 2014.S.1-42

Psacharopoulos G, Patrions HA 2002. Returns to Investment in Education: A Further Update, World Bank Policy Research Working Paper, No: 2881, S.111-134

Sarı R 2002. Kazançlar ve Eğitim İlişkisi: İl Bazında Yeni Veri Tabanı İle Kanıt, ODTÜ Gelişme Dergisi, 
$29(3-4): 367-380$.

Sarı B 2007. Uluslararası Stratejik Pazarlama Açısından İhracat Pazarlama Stratejileri ve İhracat Pazarlama Planlaması, Dokuz Eylül Üniversitesi Sosyal Bilimler Enstitüsü İşletme Anabilim Dalı, Yüksek Lisans Tezi, İzmir. S.1-157

Öztürk T 1978. 'Tutundurma', Pazarlama Yönetimi içinde, 2. Baskı, İstanbul Üniversitesi İşletme Fakültesi, Pazarlama Enstitüsü Yayını, İstanbul. Sayfa. 173
Uzgören N 2012. Bilimsel Araştırmalarda Kullanılan Temel İstatistiksel Yöntemler ve SPSS Uygulamaları, Genişletilmiş 2. Baskı, Ekin Yayınevi, Bursa.

Zenginoğlu A 2007. AB Sürecinde Türkiye Turunçgil İhracatının Yapısı, Ortaya Çıkan Sorunlar ve Çözüm Yolları Üzerine Bir Araştırma. Ege Üniversitesi, Fen Bilimleri Enstitüsü Tarım Ekonomisi Ana Bilim Dalı, Yüksek Lisans Tezi, İzmir. S.171-243 